\title{
Effects of COQ10 with vitamin E supplementation on semen quality and seminal plasma parameters of broiler breeder males
}

\author{
S.M. Raouf $\mathbb{C}^{\circ}$ and A.T. Taha \\ Department of Animal Production, College of Agriculture, University of Tikrit, Tikrit, Iraq
}

\begin{tabular}{l} 
Article information \\
\hline Article history: \\
Received December 02, 2019 \\
Accepted July 07, 2020 \\
Available online November 1, 2020 \\
\hline Keywords: \\
Semen quality \\
broiler breeder males \\
COQ10 \\
Vitamin E \\
\\
\hline Correspondence: \\
A.T. Taha \\
dr.att76@Gmail.com
\end{tabular}

\begin{abstract}
This study aimed at detecting the effects of COQ10 with and without vitamin $\mathrm{E}$ on some semen characteristics of the broiler breeder males. Twenty-five males at 43 weeks of age divided into five categories of treatment with five replicates. The first treatment (control group) included drenching with corn oil capsules only. The second and fourth treatments were about drenching with capsules containing the COQ10 enzyme at a concentration of $5 \mathrm{mg} /$ male / day with and without $10 \mathrm{mg}$ of vitamin $\mathrm{E}$ whereas the third and fifth treatments included drenching with capsules containing the Q10 enzyme at a concentration of $10 \mathrm{mg} /$ male / day with and without $10 \mathrm{mg}$ of vitamin E. This whole scheme of treatments was to study their effects on certain semen and seminal plasma properties. The results showed a significant increase $(\mathrm{P}<0.05)$ in the ejaculation volume, both individual and mass motility in addition to sperm concentration, all accrediting the fifth treatment. Furthermore, the results clear a significant decrease in the percentage of dead and abnormal sperms. The COQ10 with and without vitamin E led to improved semen quality marking a reduction in AST and ALT, glucose concentration and total protein with improved antioxidant status referring to a high level of GSH and low MDA. We conclude from this study that COQ10 with and without vitamin E has the ability to improve the semen characteristics of age-old broiler breeder males and can improve the status of antioxidants in semen.
\end{abstract}

DOI: $10.33899 /$ ijvs.2020.126287.1289, (C2021, College of Veterinary Medicine, University of Mosul.

This is an open access article under the CC BY 4.0 license (http://creativecommons.org/licenses/by/4.0/).

\section{Introduction}

The intensive genetic selection of economically important traits had a negative impact on the secondary sexual characteristics pertaining to female chicken flocks due to its negative impact on libido and male mating potential especially in fields that depend on natural mating. This ultimately led to reduced overall flock (1). At the flock level, the male to female ratio is generally $1: 10$, where male contribution towards fertility becomes significantly greater than females. and both mating activity and sperm quality decrease at an early stage of the productive period due to several factors, including the decrease in testicular mass and both the production and quality of sperms $(2,3)$.
The nature and feeding of male broilers and the high sperm production $2.2 \times 10^{9}$ sperm/day made them more susceptible to oxidative stress caused by reactive oxygen species (ROS) (4). Their production of mitochondria increases naturally or because the effects of premature aging appear on roosters $(5,6)$. These factors urged the producing companies to search for means to extend the productivity of the broiler breeder males. These factors included hereditary, nutrition and management practices (7) or rotating the roosters from hall to hall (8) as well as the addition of materials like medicinal plants that limit the production of free radicals (9) and some vitamins (10) and other transactions.

Vitamin $\mathrm{E}$ (which is a fat-soluble vitamin) is a biological chain breaking antioxidant that protects cells and 
tissues from lipid peroxidation damage by free radicals (11). Vitamin E is essential for the integrity and optimal function of the reproductive, muscular, circulatory, nervous and immune systems $(12,13)$. It's added for broiler breeder to produce fertilized eggs $(14,15)$, demonstrating its ability to improve fertility and hatching characteristics of flocks of broiler breeder, and its role in improving sperm characteristics (16).

The coenzyme Q10 known as ubiquinone is a naturally compound enzyme found in high and microorganisms. It is one of the only fat-soluble antioxidants that can be produced within the body (17). It has an important role in the respiratory chain in mitochondria of living cells that characterized by their high activity including sperm cells as well as enhancing the production of ATP (18). Q10 also protects the cellular membranes and lipids in the plasma from lipid peroxidation, and its role in renewing other antioxidants such as vitamin E and C (6). Despite its role in cases of decreased fertility and infertility (19), the research of the broiler breeder males has never been so far addressed. This study aimed at detecting the effects of COQ10 with and without vitamin $\mathrm{E}$ on some semen characteristics of the broiler breeder males.

\section{Materials and methods}

This study conducted in the animal production farm of the Animal Production Department, College of Agriculture, University of Tikrit, during the period from $25 / 2 / 2018$ to $5 / 5 / 2018$

\section{Birds and diets}

Twenty-five 43-week-old breeder roosters (Ross 308) used in this study. Following two weeks of adaptation period on experimental conditions and treatment diets. During that period, the roosters trained to respond well to collecting semen. The roosters were randomly allocated into five treatments with 5 replicates. The first treatment (control group) subjected to drenching of capsules containing corn oil only. The second and fourth treatments drenching capsules containing the COQ10 at a concentration of $5 \mathrm{mg} / \mathrm{male} /$ day with and without $10 \mathrm{mg}$ vitamin E, while the third and fifth treatments birds drenching of capsules containing the $\mathrm{CO}$ Q10 at a concentration of $10 \mathrm{mg} / \mathrm{male} /$ day with and without $10 \mathrm{mg}$ vitamin E. The roosters fed a productive diet supplemented $2700 \mathrm{Kcal} / \mathrm{kg}$ of diet and $11.5 \%$ raw protein. Water provided freely throughout the experiment.

\section{Collecting semen samples}

The seminal fluid from each rooster collected three times per week for two consecutive weeks during the four weeks comprising the study period. The collection process would be at nine o'clock in the morning right each day, with roosters deprived of both nutrients and water for no less than 5 hours to ensure a clean, uric acid-free fluid and having no waste. The semen samples collected according to the method described by (20).

\section{Seminal fluid tests}

The semen collected with $5 \mathrm{ml}$ test tubes for the following tests: ejaculation velum, mass and individual motility, percentage of dead and abnormal sperm and sperm concentration.

\section{Seminal plasma tests}

After obtaining the seminal plasma, determine semen glucose, total protein determined. Aspartate Aminotransferase (AST), Alanine Aminotransferase (ALT) activity estimated and as well as estimation of the status of antioxidants by measuring levels GSH and MDA plasma.

\section{Statistical analysis}

Statistical analysis conducted using a general linear model, procedure of SAS to evaluate the effects of treatments on reproductive traits. The differences between the means tested using the Duncan's test (21), the result with $\mathrm{P} \leq 0.05$ was considered statistically significant.

\section{Results}

The results of semen quality parameters of broiler breeder males are given in Table 1. According to the results, ejaculation volume, mass and individual motility and sperm concentration significantly $(\mathrm{P} \leq 0.05)$ improved in those male broiler breeders which received $10 / \mathrm{mg} /$ bird/day COQ10 with and without $10 \mathrm{mg} / \mathrm{bird} /$ day vitamin E drenching. The results of this table also indicated that the percentage of dead and abnormal sperms were significantly reduced in roosters that received $10 / \mathrm{mg} / \mathrm{d}$ COQ10 with and without $10 \mathrm{mg} / \mathrm{d}$ vitamin $\mathrm{E}$ drenching compared to other groups.

Effects of COQ10 with vitamin E supplementation on seminal plasma traits shown in Table 2. The results showed that the treatment with Q10 with and without vitamin E led to reducing AST enzyme activity in all treatments of the study compared with control group. Treating the drench with COQ10 at a concentration of $10 \mathrm{mg} /$ rooster with and without vitamin $\mathrm{E}$ led to reducing the ALT enzyme activity, and significantly reduced level of glucose in compared with the control group and both treatments 2 and 4. Drenching COQ10 with and without vitamin E led to a significant reduced in total protein level within the seminal plasma in all treatment compared with the control group. In addition, it has improved the status of antioxidants in the seminal plasma of broiler breeder roosters. Which represented a lower MDA level and higher GSH in all study coefficients compared with control group. 
Table 1: Effects of COQ10 with vitamin E supplementation on semen quality parameters of broiler breeder males

\begin{tabular}{lccccc}
\hline \multirow{2}{*}{ Trait } & \multirow{2}{*}{ Control } & \multicolumn{2}{c}{ COQ10 } & \multicolumn{2}{c}{ COQ10 + vitamin E } \\
\cline { 3 - 6 } & & $5 \mathrm{mg}$ & $10 \mathrm{mg}$ & $5 \mathrm{mg}+10 \mathrm{mg}$ & $10 \mathrm{mg}+10 \mathrm{mg}$ \\
\hline Ejaculate volume (ml) & $0.35 \pm 0.008^{\mathbf{C}}$ & $0.35 \pm 0.009^{\mathbf{C}}$ & $0.43 \pm 0.013^{\mathbf{A}}$ & $0.38 \pm 0.013^{\mathbf{B}}$ & $0.44 \pm 0.018^{\mathbf{A}}$ \\
Mass sperm motility (\%) & $65.34 \pm 0.772^{\mathbf{D}}$ & $70.34 \pm 0.614^{\mathbf{B}}$ & $74.81 \pm 0.820^{\mathbf{C}}$ & $71.93 \pm 0.958^{\mathbf{C}}$ & $77.33 \pm 0.948^{\mathbf{A}}$ \\
Individual motility (\%) & $71.18 \pm 0.891^{\mathbf{D}}$ & $73.89 \pm 0.958^{\mathbf{C}}$ & $78.06 \pm 0.465^{\mathbf{B}}$ & $76.99 \pm 0.946^{\mathbf{B}}$ & $80.55 \pm 0.744^{\mathbf{A}}$ \\
Dead sperm (\%) & $35.32 \pm 0.652^{\mathbf{A}}$ & $29.75 \pm 0.625^{\mathbf{B}}$ & $25.12 \pm 0.505^{\mathbf{C}}$ & $27.20 \pm 0.562^{\mathbf{D}}$ & $22.84 \pm 0.927^{\mathbf{E}}$ \\
Abnormal sperm (\%) & $27.67 \pm 0.927^{\mathbf{A}}$ & $25.06 \pm 1.304^{\mathbf{B}}$ & $21.68 \pm 0.431^{\mathbf{C}}$ & $23.73 \pm 0.652^{\mathbf{C B}}$ & $18.72 \pm 0.018^{\mathbf{D}}$ \\
Sperm concentration (x10/ml) & $3.16 \pm 0.096^{\mathbf{C}}$ & $3.38 \pm 0.079^{\mathbf{A}}$ & $3.543 \pm 0.067^{\mathbf{A}}$ & $3.388 \pm 0.059^{\mathbf{A B}}$ & $3.556 \pm 0.071^{\mathbf{A}}$ \\
\hline
\end{tabular}

Letters in same row refers to significantly different at level $\mathrm{P}<0.05$.

Table 2. Effects of COQ10 with vitamin E supplementation on seminal plasma parameters of broiler breeder males

\begin{tabular}{lccccc}
\hline \multirow{2}{*}{ Trait } & \multirow{2}{*}{ Control } & \multicolumn{2}{c}{ COQ10 } & \multicolumn{2}{c}{ COQ10 + vitamin E } \\
\cline { 3 - 6 } & & $5 \mathrm{mg}$ & $10 \mathrm{mg}$ & $5 \mathrm{mg}+10 \mathrm{mg}$ & $10 \mathrm{mg}+10 \mathrm{mg}$ \\
\hline Semen glucose $(\mathrm{mg} / 100 \mathrm{ml})$ & $12.72 \pm 0.267^{\mathbf{A}}$ & $12.27 \pm 0.348^{\mathbf{A}}$ & $10.07 \pm 0.299^{\mathbf{A}}$ & $12.23 \pm 0.359^{\mathbf{A}}$ & $9.78 \pm 0.540^{\mathbf{B}}$ \\
semen protein $(\mathrm{g} / 100 \mathrm{ml})$ & $4.95 \pm 0.165^{\mathbf{A}}$ & $4.10 \pm 0.159^{\mathbf{B}}$ & $3.43 \pm 0.053^{\mathbf{D}}$ & $3.80 \pm 0.079^{\mathbf{C}}$ & $3.42 \pm 0.088^{\mathbf{D}}$ \\
AST(IU/L) & $19.66 \pm 0.557^{\mathbf{A}}$ & $18.83 \pm 0.307^{\mathbf{A B}}$ & $16.33 \pm 0.421^{\mathbf{D}}$ & $17.83 \pm 0.477^{\mathbf{C}}$ & $17.33 \pm 0.494^{\mathbf{C D}}$ \\
ALT(IU/L) & $5.83 \pm 0.477^{\mathbf{A}}$ & $4.66 \pm 0.333^{\mathbf{A B}}$ & $4.33 \pm 0.210^{\mathbf{B}}$ & $5.16 \pm 0.477^{\mathbf{A B}}$ & $4.33 \pm 0.210^{\mathbf{B}}$ \\
GSH $\mu$ mole/mole & $0.97 \pm 0.036^{\mathbf{D}}$ & $1.76 \pm 0.217^{\mathbf{C}}$ & $2.78 \pm 0.201^{\mathbf{B}}$ & $2.81 \pm 0.056^{\mathbf{B}}$ & $3.15 \pm 0.155^{\mathbf{A}}$ \\
MDA $\mu$ mole /mole & $1.99 \pm 0.15^{\mathbf{A}}$ & $1.47 \pm 0.589^{\mathbf{B}}$ & $1.12 \pm 0.779^{\mathbf{C}}$ & $1.31 \pm 0.066^{\mathbf{B}}$ & $1.07 \pm 0.046^{\mathbf{C}}$ \\
\hline
\end{tabular}

Letters in same row refers to significantly different at level $\mathrm{P}<0.05$.

\section{Discussion}

It is noticeable from the current study that an improvement in ejaculation volume, may related to significant increase in sperms concentration. Since (9) found a positive correlation coefficient to both sperms concentration and ejaculation volume. Sperms production dependent on tests activity (22). Testes seminiferous tubules germinal layer thickness and area one of most important indicators for testes activity (9), COQ10 enzyme act to increase seminiferous tubules germinal layer thickness and area (23).

As improvement in individual and mass motility of sperms. The reason for that might be relevant reducing dead and abnormal sperms percentage $(10,9)$, for both researchers had noticed a negative correlation coefficient of high significance between individual and mass motility of sperms from one side and the percentage of dead and abnormal sperms from the other side. Sperms motility depends on several factors but the most prominent of them is the concentration of sperms. As for our own results, one can notice a significant improvement in sperms concentration accompanied with a significant drop in both percentages of dead and abnormal sperms in favor of the treatments that included addition of CO Q10 with and without vitamin $\mathrm{E}$. The improvement in individual and mass motility of sperms might attributed to COQ10 enzyme ability to enhance production of ATP from mitochondria, and hence increasing the motility of sperms, and also through its role as per transferring of electrons from complex I and complex II of the respiratory chain to complex III while in the same time transferring the protons out of the inner membrane of the mitochondria (24). Which would use eventually to activate ATPase in complex V to form ATP from ADP and inorganic phosphate (25). Where many studies referred to a correlation between sperms motility and activity of mitochondria that is present in huge amounts specifically within the mid-piece of sperms so as to cater for its high requisites of energy (26). Due to sperms relying on oxidative phosphorylation of mitochondria and cytoplasmic glycolysis (27). Increase COQ10 enzyme concentration lead to enhancing respiration and improvement Oxidative Phosphorylation (28). That is responsible for production of energy, which in turn affects sperms positively (6); the addition of Q10 enzyme has its role as per enhancing the sperms motility and confirms that there is a positive relationship between the level of Q10 enzyme within the spermatozoa and the concentrations and motility of sperms (29).The improvement in sperms motility may be due to COQ10 enzyme and vitamin $\mathrm{E}$ in protecting sperms membranes of oxidation damage (30) as well as its role as per improving the overall status of antioxidants within the semen which is regarded as the best system of protection of sperms against ROS (31).

In addition to the role of vitamin $\mathrm{E}$ as per protecting the cell from oxidation through controlling the production of $\mathrm{H} 2 \mathrm{O} 2$ directly from mitochondria, it works with COQ10 as per protecting the cell membranes from the adverse influence of peroxide (15). This is what had been confirmed by (32) while referring to the importance of administering antioxidants to enhance the concentration and motility of sperms apart of its role in reducing the effects of aging on 
sperms' motility since aging is relevant to enhanced cellular oxidation and the production of ROS (33). Bird's sperms distinguished to have high content of poly-unsaturated fatty acids, with their physical characteristics that are vital for the sperms like flexibility and fluidity that needed for motility and fertilization (34). Then it is prone to attacked by ROS and the formation of lipid peroxidation and the direct loss of motility (35). As well as the drop in the sperm-oocyte fusion which eventually leads to losing the ability of fertilization (36).

Additionally, ROS capable to damage sperm's DNA directly and indirectly via Lipid peroxidation substances. That is exist as compounds containing carbonyl like MDA and forms of 4-hydroxy-2 alkenals such as4hydroxynonenal and 2-alkenals which are regarded as both genotoxic and carcinogenic substances that affect fertility and contributes to escalate the rate of abnormalities (37).

ROS not only reduces the activity of antioxidant enzymes, it can also damage the mitochondria DNA (mtDNA) that is responsible for coding 13 of the polypeptides that are basic for transferring electrons that are present in the inner membrane of the mitochondria, thus eventually affecting oxidative phosphorylation to produce ATP via the mitochondria. Any flaw or defect in mtDNA leads to affecting the function of mitochondria membrane in an adverse manner leading to an unbalance in oxidation towards oxidative stress. Due to that, the function of mitochondria is regard as important and necessary for sperms growth and maturation (26). Thus, administering Coenzyme Q10 and vitamin E had a considerable role in improving both individual and mass motility of sperms as well as reducing the percentage of dead and abnormal sperms and improving the status of antioxidants in the semen of roosters.

Both glucose and total protein regarded as some of the most important parameters for seminal/sperm plasma being able to reflect the status and activity of the sperms it contains. Glucose considered the basic source for producing sperms energy (5) thus decreasing the concentration of glucose can offer an index to assess any increase in sperms' concentration and activity too, given here that both $(9,38)$ noticed the presence of a negative correlation between glucose concentration and sperms concentration as well as their activity.

Total protein concentration reflects the amount of the damage done in sperms cells as its concentration increases with the increase in both percentages of dead sperms and abnormal ones. ALT and AST enzymes can express the status of the sperms and its function (13). For we notice that the of both AST and ALT enzymes activity as well as total protein had been decreased for all treatments studied in comparison to the control group especially in treatments 5 and 3 which included drenching with $10 \mathrm{mg}$ of COQ10 enzyme /rooster/day with and without vitamin E, respectively.
The decreasing of these enzymes in seminal plasma might attributed to the decrease in damage processes in sperm cells. These enzymes are considered as principal enzymes available inside the sperms, their release occurs due to damages in the plasma membrane of the sperms or their death which leads to increasing the level of protein within seminal plasma (39). This result confirms the role of adding COQ10 enzyme with and without vitamin $\mathrm{E}$ as per improving the status of antioxidants and guarding the membranes of the sperms against oxidation damage.

This complies with the findings of (40), regarding a significant decrease dead and abnormal sperms percentage. As well as the activity of AST and ALT enzymes, with the increase in GST level (Glutathione S-Transferase) when antioxidants vitamins $\mathrm{E}$ and $\mathrm{C}$ are added to male rabbits due to its effectiveness as per reducing the production of free radicals as well as improving the quality of semen. This confirmed 14 of the significant improvement in the antioxidant status with the improvement of testicular function in the mice treated with the Coenzyme Q10. A positive correlation relevant to the status of total oxidation and the percentage of dead sperms in roosters of broiler breeders while there was a negative correlation of high significance between total antioxidants and the status of total oxidation and the percentage of dead sperms (41). In addition to that, the findings included a negative correlation between the effectiveness of ALT enzyme and both concentration and motility of sperms.

\section{Conclusions}

Concluded from this study that drenching broiler breeder males Coenzyme Q10 alone and with vitamin E led to a significant enhancement in semen quality when treated for eight weeks. Thus, the addition of Coenzyme Q10 along with vitamin $\mathrm{E}$ can result in extending the productive period of broiler breeder males.

\section{Acknowledgements}

The authors are grateful to the Pro. Dr. Tariq AlJumaily, Tikrit University head department of animal production for providing the laboratory facilities.

\section{Conflict of interest}

The authors declare that there is no conflict of interest.

\section{References}

1. McGary S, Estevez I, Bakst MR, Pollock DL. Phenotypic traits as reliable indicators of fertility in male broiler breeders. Poult Sci. 2002;81(1):102-111. Doi: 10.1093/ps/81.1.102

2. Sarabia FJ, Pizarro Díaz M, Abad Moreno JC, Casanovas Infesta P, Rodriguez-Bertos A, Barger K. Relationships between fertility and some parameters in male broiler breeders. Reprod Domest Anim. 2013;48(2):345-352. Doi: 10.1111/j.1439-0531.2012.02161.x 
3. Hocking PM, Bernard R. Effects of the age of male and female broiler breeders on sexual behaviour, fertility and hatchability of eggs. Brit Poult Sci. 2000;41(3):370-376. Doi: 10.1080/713654925

4. Mkpughe JI, Bratte L. Effects of breed and frequency of ejaculation on semen characteristics of chickens. Int J Livestock Res. 2015;5: 4350. 10.5455/ijlr.20150406043952

5. Amaral A, LourençoB, Marques M, Ramalho SJ. Mitochondria functionality and sperm quality. Reprod. 2013:146(5):163-174. Doi: 10.1530/REP-13-0178

6. Gvozdjáková A, Kucharská J, Dubravicky J, Mojto V, Singh RB. Coenzyme Q10, $\alpha$-tocopherol, and oxidative stress could be important metabolic biomarkers of male infertility. Disease Markers. 2015;2015:1-6. Doi: $10.1155 / 2015 / 827941$

7. Romero SH. Plumstead PW, Leksrisompong N, Brannan KE, Brake J. Feeding broiler breeder males. 4. Deficient feed allocation reduces fertility and broiler progeny body weight. Poult Sci. 2008; 87(4):805811. Doi: $10.3382 /$ ps.2007-00285

8. Zuidhof MJ, Holm DE, Renema RA, Jalal MA, Robinson FE. Effects of broiler breeder management on pullet body weight and carcass uniformity. Poult Sci. 2015;94(6):1389-1397. Doi: 10.3382/ps/pev064

9. Taha AT. The role of vitamins a, c and fenugreek seeds in lowering oxidative stress effect on physiological and reproductive performance of males broiler breeder [PhD dissertation]. Mosul: College of Agriculture and Forestry, University of Mosul, Iraq; 2008. 80-90 p.

10. Al-Daraji HJ. Effect of ascorbic acid supplementation on physiological and productive traits of Fawbro broiler breeders' flocks reared under hot climate $[\mathrm{PhD}$ dissertation]. Baghdad: College of Agriculture, University of Baghdad. 1998; 70-75 p.

11. Al-Jammas, Saif. The histological changes induced by cytarabine on rabbits kidneys (with and without vitamin $\mathrm{E}$ administration). Iraqi $\mathrm{J}$ Vet Sci. 2019;33(2):311-316. Doi: 10.33899/ijvs.2020.163563

12. Leshchinsky TV, Klasing KC. Relationship between the level of dietary vitamin $\mathrm{E}$ and the immune response of broiler chickens. Poult Sci. 2001;80(11):1590-1599. Doi: $10.1093 / p s / 80.11 .1590$

13. Khan, RU, Rahman ZU, Javed I, Muhammad F. Effect of vitamins, probiotics and protein on semen traits in post-molt male broiler breeders. Anim Reprod Sci. 2012;135(1-4):85-90. Doi: 10.1016/j.anireprosci.2012.09.005

14. Rengaraj D, Hong Y. Effects of dietary vitamin E on fertility functions in poultry species. Inter J Mol Sci. 2015;16(5):9910-9921. Doi: 10.3390/ijms16059910

15. Yaripour M, Seidavi A, Dadashbeiki M, Laudadio V, Tufarelli V, Ragni M, Payan-Carreira R. Impact of dietary supra-nutritional levels of vitamins a and e on fertility traits of broiler breeder hens in late production phase. Agricult. 2018;8(10):149. Doi: 10.3390/agriculture 8100149

16. Rakha BA, Ansari MS, Hussain I, Malik MF, Akhter S, Blesbois E. Semen characteristics of the Indian red jungle fowl (Gallus gallusmurghi). Euro J Wildlife Res. 2015;61(3):379-386. Doi: 10.1007/s10344-015-0904-x

17. Littarru GP, Bruge F, Tiano L. Biochemistry of coenzyme Q10. Androl. 2017;23-34. Doi: 10.1007/978-3-319-41749-3_2

18. Shukla S, Dubey KK. CoQ10 a super-vitamin: review on application and biosynthesis. Biotech. 2018;8(5):249. Doi: 10.1007/s13205-018$\underline{1271-6}$

19. Garrido MJ, Cordero MD, Oropesa AM, Vega, AF, De La Mata M, Pavón AD, Sánchez-Alcázar JA. Coenzyme q10 therapy. Mol Syndromol. 2014;5(3-4):187-197. Doi: 10.1159/000360101

20. Burrows WH, Quinn JP. The collection of spermatozoa from the domestic fowl and turkey. Poult Sci. 1937;16(1):19-24.

21. Duncan DB. Multiple range and multiple F teste. Biomet. 1983;11:142. Doi: $10.2307 / 3001478$

22. Vazir NM, Adibmoradi P, Tajik, MR, Babapour V and BaghcheghiY. Amorphometrical study of testis and histometrical study of seminiferous tubules in Coenzyme Q10 fed ostriches. J Vet Res. 2013;68(4):349-357. Doi: 10.22059/2013.35016

23. Raouf SM. Effect drenching Coenzyme Q10 and vitamin E in semen quality and some blood traits for Broiler breeder males Ross $308[\mathrm{PhD}$ thesis]. Tikrit: College of Agriculture, University of Tikrit, Tikrit; 2019. 107-109 p.

24. Hamideh RV, Hoda JM, Aydin B. Coenzyme Q10 and its Effective Sources. Am J Biochem Biotechnol. 2016;12(4):214.219. Doi: 10.3844/ajbbsp.2016.214.219

25. Casagrande D, Waib PH, Júnior AA. Mechanisms of action and effects of the administration of Coenzyme Q10 on metabolic syndrome. J Nutrit Inter Metabol. 2018;13:26-32. Doi: 10.1016/j.jnim.2018.08.002

26. Kamali SA, Masoudi AA, Vaez TR. Association of mitochondrial function and sperm progressivity in slow-and fast-growing roosters. Poult Sci. 2017;96(1):211-219. Doi: 10.3382/ps/pew273

27. Bottje WG, Carstens GE. Association of mitochondrial function and feed efficiency in poultry and livestock species. J Anim Sci. 2009;87(14):48-63. Doi: 10.2527/jas.2008-1379

28. Lafuente R, González CM, Solà I, LG, Brassesco M, Carreras R, Checa MA. Coenzyme Q10 and male infertility: a meta-analysis. J Assist Reprod Genet.2013;30(9):1147-1156. Doi: 10.1007/s10815013-0047-5

29. Balercia G, Buldreghini E, Vignini A, Tiano L, Paggi F, Amoroso S, Littarru G. Coenzyme Q10 treatment in infertile men with idiopathic asthenozoospermia: A placebo-controlled, double-blind randomized trial. Fertil Steril. 2009;91(5):1785-1792. Doi: 10.1016/j.fertnstert.2008.02.119

30. Kobori Y, Ota S, Sato R, Yagi H, Soh S, Arai G, Okada H. Antioxidant cosupplementation therapy with vitamin $\mathrm{C}$, vitamin $\mathrm{E}$, and coenzyme Q10 in patients with oligoasthenozoospermia. Arch Urol Androl. 2014;86(1):1-4. Doi: 10.4081/aiua.2014.1.1

31. Nadjarzadeh A, Sadeghi MR, Amirjannati N, Vafa MR, Motevalian SA, Gohari MR, Shidfar F. Coenzyme Q 10 improves seminal oxidative defense but does not affect on semen parameters in idiopathic oligoasthenoteratozoospermia: A randomized double-blind, placebo controlled trial. J Endocrinol Invest. 2011;34(8):224-228. Doi: $10.3275 / 7572$

32. Khan RU. Antioxidants and poultry semen quality. World's Poult Sci J. 2011;67(2):297-308. Doi: 10.1017/S0043933911000316

33. Eskenazi B, Kidd SA, Marks AR, Sloter E, Block G, Wyrobek AJ. Antioxidant intake is associated with semen quality in healthy men. Hum Reprod. 2005;20(4):1006-1012. Doi: 10.1093/humrep/deh725

34. Guthrie HD, Welch GR. Effects of reactive oxygen species on sperm $\begin{array}{lll}\text { function. Theriogenol. 2012;78(8):1700-1708. Doi: } & \end{array}$ 10.1016/j.theriogenology.2012.05.002

35. Moazamian R, Polhemus A, Connaughton H, Fraser B, Whiting S, Gharagozloo P, Aitken RJ. Oxidative stress and human spermatozoa: Diagnostic and functional significance of aldehydes generated as a result of lipid peroxidation. Basic Sci Reprod Med. 2015;21(6):502515. Doi: $10.1093 / \mathrm{molehr} / \mathrm{gav} 014$

36. Opuwari CS, Henkel RR. An update on oxidative damage to spermatozoa and oocytes. Bio Med Res Inter. 2016;16:1-11. Doi: 10.1155/2016/9540142

37. Burcham PC. Genotoxic lipid peroxidation products: their DNA damaging properties and role in formation of endogenous DNA adducts. Mutagenesis. 1998;13(3):287-305. Doi: 10.1093/mutage/13.3.287

38. Al-Daraji HJ. Sperm-egg penetration in laying breeder flocks: a technique for the prediction of fertility. Brit Poult Sci. 2001;42(2):266-270. Doi: 10.1080/00071660120048537

39. Buckland RB. The activity of six enzymes of chicken seminal plasma and sperm: Effect of in vitro storage and full sib families on enzyme activity and fertility. Poult Sci. 1971;50(6):1724-1734. Doi: 10.3382/ps.0501724

40. Yousef MI, Abdallah GA, Kamel KI. Effect of ascorbic acid and vitamin $\mathrm{E}$ supplementation on semen quality and biochemical parameters of male rabbits. Anim Reprod Sci. 2003;76(1-2):99-111. Doi: $10.1016 / \mathrm{S} 0378-4320(02) 00226-9$

41. Ali, SM, Nawfal AJ, Al-Okaily BN. Protective effects of coenzyme Q10 against sodium fluoride-induced reproductive disorders in male rats. Iraqi J Vet Sci.2019; 33(1): 143-149. Doi: 10.33899/ijvs.2019.125534.1056 


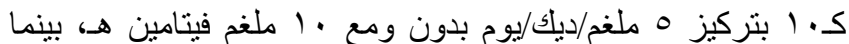

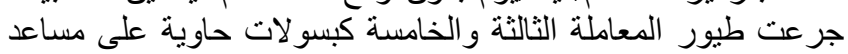

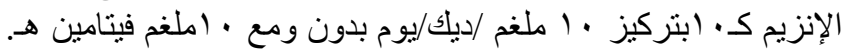

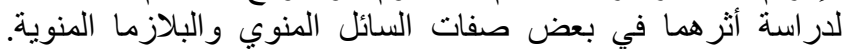

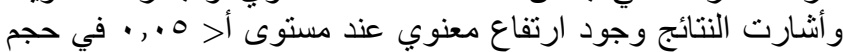

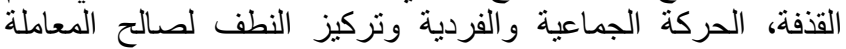

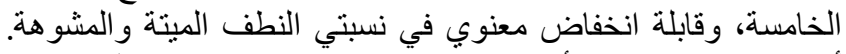

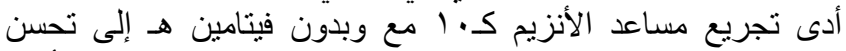

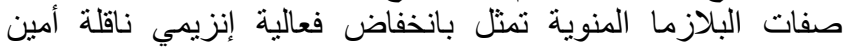

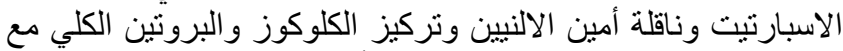

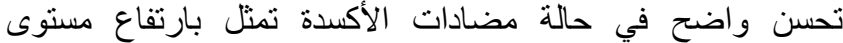

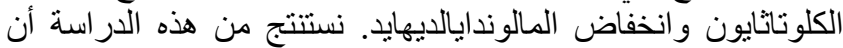

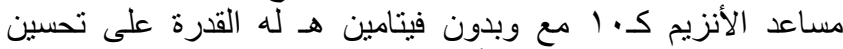

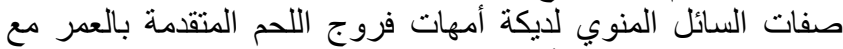
تحسين حالة مضادات الأكسدة في السائل المنوي.
تأثير مساعد الأنزيم ك ، أ مع وبدون إضافة فيتامين

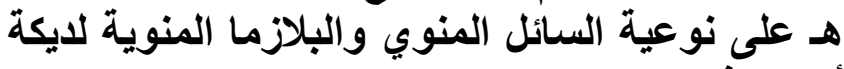
أمهات فروج اللحم فلة التم

سماح ميسر رؤوف وأحمد طايس طه

قسم الإنتاج الحيو اني، كلية الزر اعة، جامعة تكريت، تكريت، العراق

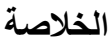

هدفت هذه الدراسة معرفة نأثير مساعد الإنزيم ك. إن مع وبدون

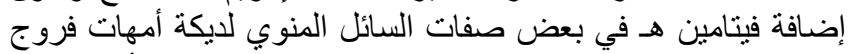

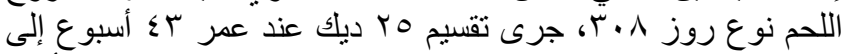

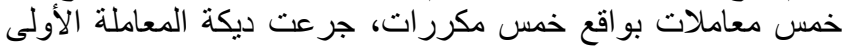

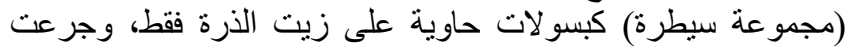
ديكة المعاملة الثانية والرابعة كبسولات حاتهة حاوية على مساعد الإنزيم 